\title{
Effects of some ecological variables on carabid communities in native and non native forests in the Ibaizabal basin (Basque Country: Spain)
}

\author{
Adoración MARTíneZ ${ }^{1}$, Juan Carlos ITURRondobeitia ${ }^{2}$, Arturo GoldARAZENA $^{1 *}$ \\ ${ }^{1}$ Departamento de Producción y Protección Vegetal, Instituto Vasco de Investigación y Desarrollo Agrario (NEIKER-TECNALIA), Granja Modelo \\ Arkaute, Apdo. 46, 01080 Vitoria-Gasteiz, Álava, Spain \\ ${ }^{2}$ Departamento de Zoología y Biología Celular Animal, Universidad del País Vasco, Sarriena s/n, 48940, Leioa, Bizkaia, Spain
}

(Received 14 September 2007; revised version 16 April 2008; accepted 28 October 2008)

Keywords:

carabid beetles /

forest habitats /

ecological variables /

forest management /

biodiversity

\begin{abstract}
- Carabid beetles were investigated at five different forest types in the Ibaizabal basin (northern Spain). The landscape is characterized by the presence of remnants of native forest surrounded by conifer plantations.

- Carabids were trapped in 52 stands of mixed forest, beech forest, holm oak forest, mixed pine and Monterey pine plantations in 2005 and 2006. The main objectives of the study were: compare carabid diversity, recognise the characteristic species, and study the effects of ecological variables on carabid assemblages in the different forest types.

- No significative differences in species abundance, richness and diversity were found among the studied forests. Most of the trapped beetles were identified as forest generalists, nevertheless some native and non-native forest specialist species were also found. Distribution of carabid communities overlapped and, except for beech forest, no specific communities were distinguished. Altitude, percentage of grass coverage and temperature were the main variables influencing species distribution.

- The results suggest high habitat homogeneity, caused by regeneration in pine plantations of the indigenous understorey, and by poor habitat quality in native forest (patchy remnants enclosed in conifer plantations). This situation could explain the similar carabid diversity.
\end{abstract}

Résumé - Effets de certaines variables écologiques sur les communautés de carabidés autochtones et non autochtones des forêts dans le bassin Ibaizabal au Pays Basque espagnol.

- Les carabidés ont été étudiés dans cinq différents types de forêts dans le bassin Ibaizabal (nord de l'Espagne). Le paysage est caractérisé par la présence de vestiges de la forêt naturelle entourés par des plantations de conifères.

- Les carabidés ont été piégés en 2005 et 2006, dans 52 peuplements de forêts mixtes, hêtraies, chênaies vertes, peuplement mélangé de pins et plantations de pins de Monterey. Les principaux objectifs de l'étude ont été : la comparaison de la diversité des carabidés, la reconnaissance des espèces caractéristiques, et l'étude des effets des variables écologiques sur les assemblages de carabidés dans les différents types de forêts.

- Parmi les forêts étudiées, il n'a pas été mis en évidence de différences significatives pour ce qui concerne l'abondance des espèces, la richesse et la diversité. La plupart des coléoptères piégés ont été identifiés comme étant des généralistes des forêts, néanmoins certaines espèces autochtones et non autochtones des forêts ont également été trouvées. Les répartitions des communautés de carabidés se chevauchent et, à l'exception des hêtraies, aucune communauté spécifique n'a été distinguée. L'altitude, le pourcentage de couverture herbacée et la température ont été les principales variables qui ont influencé la répartition des espèces.

- Les résultats obtenus suggèrent que la haute homogénéité de l'habitat est causée par la régénération d'un sous-bois d'espèces naturelles dans les plantations de pins, et par la mauvaise qualité de l'habitat dans la forêt naturelle (restes fragmentaires de forêts entourés par des plantations de conifères). Cette situation pourrait expliquer la diversité similaire des carabidés.

\footnotetext{
*Corresponding author: agoldarazena@ neiker.net
} 


\section{INTRODUCTION}

Natural ecosystems and biodiversity provide many goods and services to human society that are of great ecological, socio-cultural and economic value (de Groot, 2006). As a result of the increasing interest in the proper use and maintenance of the goods and services offered by forests to society, many forest owners of the Basque Country have recently joined the PEFC (Panaeuropean Forest Council) certification. This system is supposed to guarantee the consumer that wood purchased comes from a sustainably managed forest.

Nearly $55 \%$ of the territory in the Basque Country is covered with forests, 53\% being non-native conifers or Eucalyptus species (Inventario Forestal de la CAE, 2005) with a very variable distribution according to the provinces. The increasing area covered with plantations makes of great relevance their contribution to the conservation of global forest diversity (Jactel et al., 2004). Moreover the recent ecocertification scheme creates a need to evaluate whether current forest management is compatible with long-term conservation of biodiversity in the pine monoculture (Barbaro et al., 2005). Sustainable forest management is a widely held international goal that aims the development of some criteria for maintenance, conservation and development of biological diversity (Montreal Process, 2000; UNCSD, 2001).

Fragmentation is one of the greatest environmental problems all over the world and it is one of the most important reasons for declining biodiversity (Pimm and Gilpin, 1989). Human-induced changes in native forest habitats have had direct impact on landscape morphology, contributing to creation of a fragmented landscape where only some remnants of seminatural forest are present. Monitoring of changes in the local fauna and their comparison with native communities is important for assessing human impact on biological diversity (Lenski, 1982).

As it is impossible to measure and monitor the effects of forest management on all species or environmental conditions of interest, monitoring a few indicator species is an intuitively appealing method of measuring the ecological sustainability of forest management (Landres et al., 1988).

Soil dwelling invertebrates such as carabid beetles and spiders have strong potential as ecological indicators (Pearce and Venier, 2006). Ground beetles have been used widely as indicators of faunal composition to define habitat change and to compare habitat types (Jukes et al., 2001). They are favourable subjects for comparative ecological studies of the human impact on biodiversity, because they are abundant, their ecology and systematics are well known (Lövei and Sunderland, 1996), their data collection is cost-effective, they show wide habitat requirements (Rainio and Niemelä, 2003) and they are very sensitive to changes in their environment (Ings and Hartley, 1999; Niemelä et al., 2000; Thiele, 1977). Comparative analysis among different taxa to environmental variables have been carried out, amongst others, on carabids and plants (Fahy and Gormally, 1998; Poole et al. 2003), on carabids and oribatid mites (Migliorini et al., 2002), on communities of birds, spiders and carabids (Barbaro et al., 2005). Forest management studies on carabid assemblages within natural, managed and unmanaged conifer and deciduous forest have been carried out. Some of them focus on forestry and habitat fragmentation (Magura, 2002; Niemelä, 2001; Niemelä et al., 2007), others on habitat structure and composition (Ings and Hartley, 1999; Jukes et al., 2001; Magura et al., 2000; Taboada et al., 2006), and others on biodiversity conservation (Butterfield et al., 1995; de Warnaffe and Lebrun, 2004; Gutiérrez et al., 2004).

Comparisons among habitat types are needed to reveal more accurately different species habitat requirements and the relative species diversity of carabid assemblages in different habitats (Niemelä and Halme, 1992). Our study focuses on the influence of some ecological variables in a very disturbed area where a few, native semi-natural dispersed forests are embedded in a matrix of non-native commercial plantations, and on the contribution per se of the different forests to the maintenance and conservation of local biodiversity.

The study was done to examine the community composition of carabid beetles (Coleoptera: Carabidae) in different forest types in the Ibaizabal basin (Basque Country, Spain). More specifically we aimed to: (1) compare the carabid beetle diversity of different native and non-native forest types, (2) find possible characteristic species for the sampled forests, (3) study the effects of some ecological variables on the carabid assemblages.

\section{MATERIALS AND METHODS}

\subsection{Study area}

The study was conducted in the Ibaizabal basin $\left(43^{\circ} 07^{\circ} \mathrm{N}, 2^{\circ}\right.$ $51^{\prime} \mathrm{W}$ ), located in the North of Spain (Basque Country). The basin is situated in the eurosiberian climatic zone with a mean annual temperature of $14{ }^{\circ} \mathrm{C}$ and an annual regular rainfall with an average of $1170 \mathrm{~mm}$. The altitude ranges from low elevations (less than $50 \mathrm{~m}$ a.s.1.) to $1200 \mathrm{~m}$ (GESPLAN, 2002).

The typical native forest studied belonged to Carici sylvaticaeFagetum sylvaticae (beech forest), Polysticho setiferi-Fraxinetum excelsioris (Atlantic mixed forest) and Lauro nobilis-Quercetum ilicis (holm oak forest) botanical associations (Loidi et al., 2005). Native forest has been gradually substituted by exotic commercial plantations, mainly intensive monocultures of Monterey pine (Pinus radiata) that now dominates the landscape below the $600 \mathrm{~m}$. From the 48320 ha of the basin, 31889 ha (66\% of the total area) are woodlands. Commercial plantations represent $82 \%$ of the total forested area, and Pinus radiata covers $63 \%$ of the forested area (Inventario Forestal de la CAE, 2005). The principal uses in the area are forestry and agriculture. Moreover, it is a very industrialized and populated area with a highly fragmented landscape (Orive and Rallo, 2002).

Five different forest habitat types were sampled: Atlantic mixed forest ("MF"), beech forest ("BE"), holm oak forest ("HO"), mixed pine plantation ("MP") and Pinus radiata plantation ("PR"). Those Pinus radiata plantations with more than a $15 \%$ of their coverage occupied by deciduous species were grouped under mixed pine plantations. 


\subsection{Sampling design and field methods}

The study took place in 52 sampling sites located in native and non-native forest patches distributed all over the basin. Sampling sites were circular stands (plots) of $25 \mathrm{~m}$ radius $(0.20 \mathrm{ha}$ ) and the minimum distance between them was $1 \mathrm{~km}$. In each stand five pitfall traps were located. The first in the middle of the stand and the other four $10 \mathrm{~m}$ away in North, South, East and West directions. (A map of the distribution of the sites is available at www.afs-journal.org as Fig. A).

We studied 12 "MF", 9 "BE", 8 "HO", 5 "MP" and 18 "PR". Stands were distributed following the methodology of the Spanish National Forest Inventary (IFN2, 1998). As in the previous IFN2 (1998) a metal tube was buried into the middle of each stand that was localized using aerial photographs, UTM coordinates and a metal detector. Size of the forest patches varied with a mean size of 2.7 ha for "MF", 61.18 ha for "BE", 14.2 ha for "HO", 29.45 ha for "MP" and 46.16 ha for "PR". It was not possible to sample in larger "MF" as well as to choose enough replicates of different age classes to analyze changes among the classes.

Beetles were sampled using pitfall traps with a diameter of $200 \mathrm{~mm}$ and a volume of $500 \mathrm{~mL}$. Each trap was filled in with $100 \mathrm{~mL}$ ethylene glycol, a non-attractive alcoholic preservative, and $100 \mathrm{~mL}$ of water, and set into the ground with the rim flush to the soil surface. Trapping was carried out continuously from July to November 2005 and from April to June 2006.

Traps were emptied and replaced once every 2 weeks. Trapped carabids were identified to species level using morphological keys by Jeannel (1941; 1942), Hùrka (1996) and Ortuño and Marcos (2003), and following the nomenclature of Serrano (2003).

Pooled data used in data analysis refers to beetle catches per trap and forest stand type.

\subsection{Ecological variables}

All sites were characterised by a range of ecological variables: (1) altitude (m a.s.1.), (2) mean annual temperature $\left({ }^{\circ} \mathrm{C}\right),(3)$ mean annual rainfall (mm), (4) freeze free period (months), (5) vegetative period (months), (6) tree height $(\mathrm{m})$, (7) leaf litter layer coverage $(\%)$, (8) shrub coverage (\%), (9) grass coverage (\%), (10) number of tree species present.

(1) Altitude was proportioned at each location by a digital terrain model (DTM) where stand UTM coordinates were introduced. (2) mean annual temperature, (3) mean annual rainfall, (4) freeze free period, months with temperatures continuously over $0{ }^{\circ} \mathrm{C}$ and (5) vegetative period, months of plant biological activity, was calculated using a modelizing software (Ortubay, 1995). This software created for the whole territory of the Basque Country allows introducing UTM coordinates of each stand the access to climatic and vegetative information. (6) Tree height was calculated for the 10 trees of largest diameter in the stand using a digital hipsometer. In this way the mean height of the dominant species of each plot was estimated. (7) Leaf litter layer, (8) shrub and (9) grass coverage were visually estimated in percentage for the whole stand. (10) total number of tree species present at each site was counted.

\subsection{Data Analysis}

Anova was used to determine differences in carabid assemblage structure among habitat types. One-way Anova with Scheffé multiple comparisons post hoc test, appropriate for unequal group sizes and more than 3 groups were used to assess differences in carabid species richness, diversity and abundance per trap and forest stand type among the studied forests. One-way Anova depends on the assumption that data follow a normal distribution and that the samples were drawn from populations with the same variance. A Kolmogorov-Smirnov test was used to check species richness, diversity and abundance per trap for normality. The equal variance of the samples was analysed by a Levene's test (Sokal and Rohlf, 1981). The abundance of individuals needed to be transformed (ln) to achieve a normal distribution. The analyses were done by SPSS-PC program.

The indicator value (IndVal) was applied to find characteristic species (Elek et al., 2001) and species assemblages characterising the "MF", "BE", "HO", "MP" and "PR" plantations. The novelty of this approach lies in the way it combines a species relative abundance to its relative frequency of occurrence in the groups of samples. Statistical significance of the species indicator values is evaluated using a randomisation procedure. A classification of sample units is required for this approach (Dufrêne and Legendre, 1997). In the present study the classification was hierarchically defined taking into account nativeness and biotype of the forest.

Different samples were classified according to their beetle species composition by correspondence analysis (CA). Variables affecting the distribution of beetles were examined using canonical correspondence analysis (CCA). (Scaling type: biplot, no data transformation and downweighting of rare species.) All ordinations analysis were made using CANOCO program, version 4.0 (Ter Braak and Šmilauer, 1998) which allows multivariate and direct gradient analysis of response data with respect to a set of explanatory variables. To test the significance of the eigenvalue corresponding to the first CCA canonical axis, a Monte-Carlo permutation test was performed. Species which occurred in very few plots were down weighted to reduce the risk of analysis distortion.

\section{RESULTS}

\subsection{Species abundance, richness and diversity}

A total of 12073 individuals belonging to 27 different carabid species were collected. The catch was dominated by 5 species common to all habitats: Steropus gallega (25.75\%), Carabus nemoralis (23.08\%), Abax parallelepipedus (20.99\%), Carabus lineatus (12.07\%) and Carabus purpurascens (7.89\%). These made up almost $90 \%$ of the total individuals captured (Tab. I).

More than half of the beetle catches per trap and forest stand type $(60 \%)$ were obtained from the pine plantations ("PR" $25 \%$ + "MP" $35 \%$ ). On the contrary, captures in "HO" represented only a $6 \%$ of the total captures and $17 \%$ in "BE" and "MF".

The greatest number of species was collected from the "MF" (20 species), closely followed by the "BE" habitat (18 species). "PR", "MP" and "HO" presented a lower number of species (16, 15 and 12, respectively) (Tab. II). However Anova did not indicate significant differences neither in mean carabid species richness, nor in Shannon diversity or abundance per trap and forest stand type. 
Table I. List of carabid species in terms of abundances (number of individuals) and frequency of occurrence in sample plots of the same type (in brackets).

\begin{tabular}{|c|c|c|c|c|c|c|}
\hline \multirow[t]{2}{*}{ Species } & \multicolumn{6}{|c|}{ Habitat and number of sites of each } \\
\hline & $\begin{array}{c}\text { MF } \\
n=12\end{array}$ & $\begin{array}{c}\mathrm{BE} \\
n=9\end{array}$ & $\begin{array}{c}\mathrm{HO} \\
n=8\end{array}$ & $\begin{array}{c}\text { MP } \\
n=5\end{array}$ & $\begin{array}{c}\text { PR } \\
n=18\end{array}$ & $\begin{array}{c}\text { Total } \\
n=52\end{array}$ \\
\hline Steropus gallega* & $495(11)$ & $521(8)$ & $146(6)$ & $415(5)$ & $1532(17)$ & $3109.95(47)$ \\
\hline Carabus nemoralis & $515(11)$ & $286(9)$ & $124(8)$ & $596(5)$ & $1266(17)$ & $2787.88(50)$ \\
\hline Abax parallelepipedus & $519(9)$ & $437(9)$ & $157(6)$ & $488(4)$ & $933(18)$ & $2534.97(46)$ \\
\hline Carabus lineatus & $330(10)$ & $137(8)$ & $91(8)$ & $162(3)$ & $737(16)$ & $1457.45(45)$ \\
\hline Carabus purpurascens & $71(5)$ & $117(9)$ & $49(5)$ & $274(2)$ & $441(11)$ & $952.31(32)$ \\
\hline Carabus cancellatus & $146(3)$ & $24(1)$ & 0 & $7(1)$ & $134(7)$ & $311.08(12)$ \\
\hline Pterostichus cristatus & $51(5)$ & $172(5)$ & 0 & $27(2)$ & $52(9)$ & $302.13(21)$ \\
\hline Carabus auratus & $228(2)$ & 0 & 0 & $1(1)$ & $9(3)$ & $238.10(6)$ \\
\hline Carabus convexus & 0 & $16(4)$ & $2(2)$ & $26(2)$ & $81(4)$ & $125.02(12)$ \\
\hline Carabus splendens & $1(1)$ & $69(5)$ & $1(1)$ & $2(2)$ & $15(5)$ & $88.04(14)$ \\
\hline Laemostenus oblongus* & $3(1)$ & $20(6)$ & $1(1)$ & $28(3)$ & $28(7)$ & 80.03 (18) \\
\hline Nebria brevicollis & $3(2)$ & $9(2)$ & $1(1)$ & $1(1)$ & $4(1)$ & $18.01(7)$ \\
\hline Carabus macrocephalus & $3(2)$ & $3(2)$ & $2(1)$ & $3(3)$ & $3(2)$ & $14.01(10)$ \\
\hline Cychrus spinicollis* & 0 & $11(3)$ & 0 & 0 & 0 & $11.01(3)$ \\
\hline Poecilus cupreus & $10(2)$ & 0 & 0 & 0 & 0 & $10(2)$ \\
\hline Calathus fuscipes & 0 & $8(2)$ & 0 & 0 & 0 & $8(2)$ \\
\hline Cicindela campestris & $1(1)$ & $1(1)$ & $3(1)$ & 0 & $1(1)$ & $6.01(4)$ \\
\hline Harpalus dimidiatus & $2(1)$ & $2(1)$ & 0 & 0 & 0 & $4(2)$ \\
\hline Licinus aequatus* & 0 & $1(1)$ & $2(2)$ & $1(1)$ & 0 & $4(4)$ \\
\hline Pterostichus nigrita & $4(1)$ & 0 & 0 & 0 & 0 & $4(1)$ \\
\hline Platyderus pyrenaeus* & $3(1)$ & 0 & 0 & 0 & 0 & $3(1)$ \\
\hline Brachinus elegans & $2(1)$ & 0 & 0 & 0 & 0 & $2(1)$ \\
\hline Pseudophoonus rufipes & 0 & 0 & 0 & $2(2)$ & 0 & $2(2)$ \\
\hline Amara montivaga & $1(1)$ & 0 & 0 & 0 & 0 & $1(1)$ \\
\hline Brachinus sclopeta & $1(1)$ & 0 & 0 & 0 & 0 & $1(1)$ \\
\hline Harpalus latus & 0 & 0 & 0 & 0 & $1(1)$ & $1(1)$ \\
\hline Platynus assimilis & 0 & $1(1)$ & 0 & 0 & 0 & $1(1)$ \\
\hline Total & 2389 & 1835 & 579 & 2033 & 5237 & 12077 \\
\hline
\end{tabular}

MF: atlantic mixed forest; BE: beech forest; HO: holm oak forest; MP: mixed pine plantations; PR: Pinus radiata plantations. $n=$ total number of sites within each habitat. Species in bold type were common to all habitats. * Species endemic to the Iberian Peninsula (Jeannel, 1942; Jiménez-Valverde and Ortuño, 2007).

Table II. Carabid species richness, mean species richness, abundance and Shannon diversity per sampling plot for the 5 analyzed forest types.

\begin{tabular}{lcccc}
\hline Habitat & Species richness & Mean species richness \pm S.D. & Mean abundance \pm S.D. & Mean Shannon diversity \pm S.D. \\
\hline MF & 20 & $5.83 \pm 2.725$ & $198.50 \pm 275.270$ & $1.91 \pm 0.558$ \\
BE & 18 & $8.67 \pm 2.000$ & $204.11 \pm 176.653$ & $2.27 \pm 0.423$ \\
HO & 12 & $5.25 \pm 2.188$ & $72.38 \pm 79.513$ & $1.79 \pm 0.499$ \\
MP & 15 & $7.40 \pm 4.037$ & $406.60 \pm 512.922$ & $1.67 \pm 0.712$ \\
PR & 16 & $6.67 \pm 2.142$ & $291.00 \pm 271.886$ & $1.88 \pm 0.354$ \\
\hline
\end{tabular}

MF: Atlantic mixed forest; BE: beech forest; HO: holm oak forest; MP: mixed pine plantations; PR: Pinus radiata plantations.

\subsection{Carabid habitat classification}

Carabid species were classified into 3 groups by characterisation of habitats by characteristic species (Fig. 1). (Two-way indicator table is available at www.afs-journal.org as Tab. A.)

(a) Forest generalists that occurred numerously in all forest types; (b) native forest specialists that occurred exclusively or most abundantly in the forest with native trees; and (c) nonnative forest specialists, that were captured exclusively or most abundantly in the non-native forest. (a) Forest generalists were represented by Carabus nemoralis, Steropus gallega, Abax parallelepipedus, Carabus lineatus, Carabus purpurascens, Pterostichus cristatus, Carabus cancellatus, Carabus convexus and Nebria brevicollis. (b) Native forest specialists were represented by 3 species. Carabus splendens and Cychrus spinicollis were significantly bioindicators for "BE" and Carabus auratus was bioindicator for "MF" although not significantly. (c) Nonnative forest specialists were represented by Laemostenus oblongus and Carabus macrocephalus. Both significantly were bioindicators for "MP". 


\section{Forest}

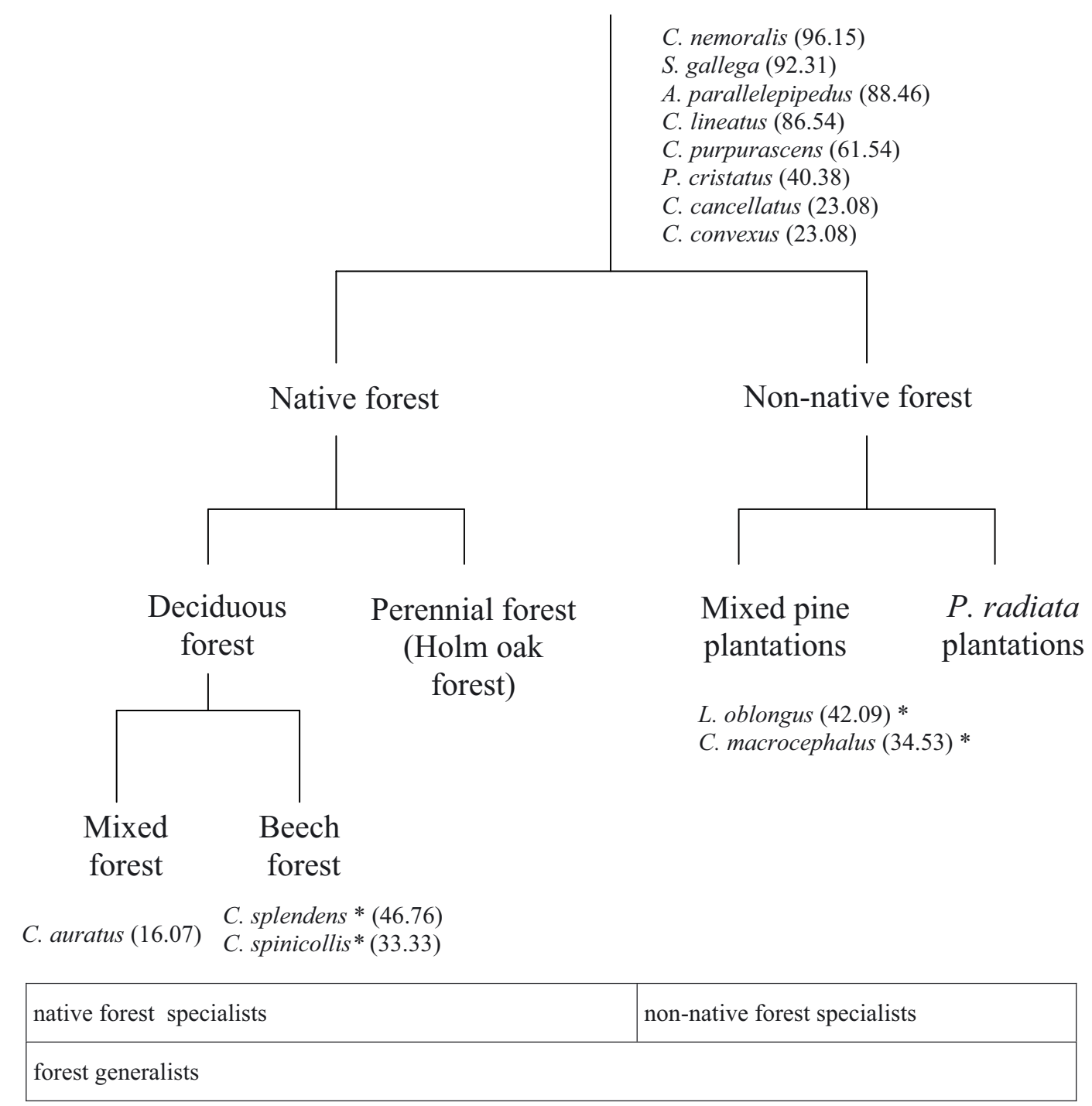

Figure 1. Dendrogram of the IndVal indicator-species analysis showing the characteristic species (full names in Tab. I) found for each habitat type, and a schematic presentation of the different categories in the boxes. Characteristic species are denoted by $*(p<0.05)$. Only species represented by ten or more individuals are shown.

The relative proportions of forest generalists and specialists for habitat type (Fig. 2) show that more than $90 \%$ of the individuals captured belonged to generalist species.

\subsection{Correspondence analysis (CA) of stands based on carabid composition}

Stand distributions depending on carabid abundances were studied by a CA. Summary statistics data appear in Table III. The first two axes (Fig. 3) account for $40 \%$ of the total variation observed in the carabid assemblage, highlighting a very mixed distribution of stands. Nevertheless, a group of four beech forests (circles located up-left in the fourth quadrant) are closed related and share differentiated communities. Especially relevant are populations of Carabus splendens and Pterostichus cristatus at these four sites which are situated at higher altitude.

A Pinus radiata group (three adjacent down-triangles of the first quadrant) seem to share very similar communities although they are not linked to any of the species of carabids.

The isolated stand of PR (down-triangle up in the fourth quadrant) and the MF (square in the right of the first quadrant) present communities that differed not only from the forest of their same type but also from the rest of sites studied.

The rest of the stands clustered in the centre of the ordination diagram present a very mixed distribution of shared communities. Carabid species centrally located do not seem to 


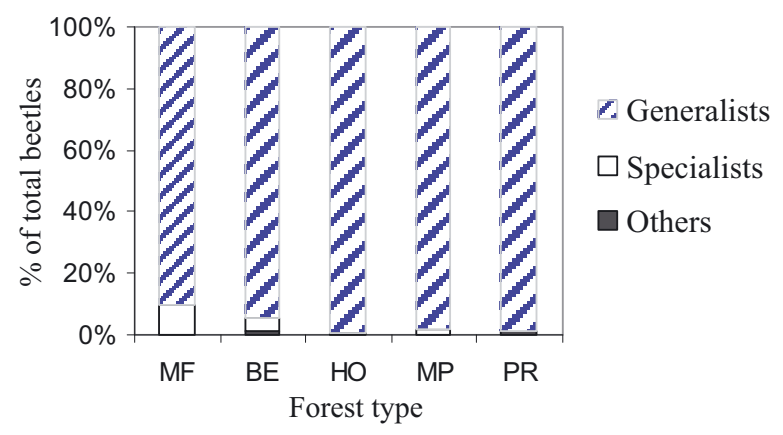

Figure 2. Habitat preferences (Number of individuals). Relative proportions (in \%) of carabid beetle groups associated with the forest type in which they were present. MF: Atlantic mixed forest; BE: beech forest; HO: holm oak forest; MP: mixed pine plantations; PR: Pinus radiata plantations.

be associated with any type of forest. Distributions are overlapped, not presenting specific communities by forest type.

\subsection{Ecological variables affecting the carabid community. CCA analysis}

The CCA analysis (summary statistics data in Tab. IV) explained only $27 \%$ of the total variation indicating that some other important variance was not included (Fig. 4).

Relationships between species data and ecological variables measured (altitude, temperature, rainfall, freeze free period, vegetative period, tree height, leaf litter layer coverage, shrub coverage, grass coverage and number of tree species) showed significant influence in the carabid community distribution.

Steropus gallega, Carabus nemoralis, Abax parallelepipedus, Carabus lineatus and Carabus purpurascens assemblages were clustered in the center of the ordination diagram showing undifferentiated pattern. No habitat preferences based on the chosen ecological variables were detected for those species. On the contrary less abundant species showed more specific habitat requirements. Pterostichus cristatus and Carabus splendens were mainly influenced by the altitude of the location. Carabus auratus assemblages were affected by freeze free period. Carabus cancellatus populations seem to develop better in sites with high percentages of grass. Presence of these latter two species was influenced by temperature and linked to site warmth. Carabus convexus was influenced by percentage of grass cover and altitude, and Laemostenus oblongus was influenced also by altitude. Variables affecting other species were temperature and altitude, defining a possible temperature gradient, with Carabus cancellatus and Carabus auratus clearly preferring warmer sites, whereas Carabus splendens, Pterostichus cristatus and Laemostenus oblongus preferred cooler ones.

\section{DISCUSSION}

The carabid community of the Ibaizabal basin presents an abundance pattern similar to other places, where only a very few species were abundant (Fahy and Gormally, 1998; Magura et al., 2005; Poole et al., 2003). All of them are brachypterous species positively involved with the stability of an ecosystem because of their low dispersal ability (Brandmayr et al., 1983).

As predators, carabids are not strictly associated with food plants, but high "biological productivity" and habitat diversity may increase numbers of invertebrate herbivores, i.e. carabid prey, and thus indirectly affect carabid abundance (Halme and Niemelä, 1993). Rare or numerous species might be affected by available food resources. On the soil surface, numbers of other invertebrates caught varied in the same way as the carabids (Butterfield, 1992). Abundance of carabid individuals on the studied pine (Pinus radiata + mixed pine) plantations is relatively high compared with the analysed native forest. This could be explained by sufficiently rich food resources and relatively low predation rates in those habitats.

Ground beetles have been used widely as indicators of faunal composition to compare habitat types (Jukes et al., 2001). Many studies comparing forest types focused on the differences found in the biodiversity of semi-natural native forests and non-native conifer plantations. Carabid species richness was lower in the plantations than in deciduous forest in northern England (Butterfield et al., 1995) and in Ireland (Fahy and Gormally, 1998). Also in Hungary, Magura et al. (2003) found that carabid species richness was significantly lower in plantations than in native beech forest. Nevertheless such a pattern is not followed in places where conifer trees form the native forest. Species richness was observed in lodgepole pine forests to be greater than in mixed species forest (Spence et al., 1996). Our results, however do not agree with previous studies. In the studied area no significative differences in abundance, species richness or diversity were found between the native forest types and pine plantations. The fact that the carabid fauna of coniferous forests is not poorer in species than that of deciduous forests is supported by Magura et al. (2000) who found similar species richness and diversity in a native forest and a managed conifer plantation. In both studies, recolonisation by shrubs and herbs of the native vegetation took place, with the plant composition as well as the structure and thickness of the leaf litter layer becoming similar to that of native forest. To maintain diverse species assemblages in a landscape it is important to preserve heterogeneity of habitats (Niemelä, 2001). Similarity in the composition of carabid communities of plantations and native forests may be explained by microclimatic conditions, specially the structure of vegetation and the litter layer (Magura et al., 1997). Conservation management practice that encourages re-invasion by native herbs, shrubs and trees through thinning and creating gaps contributes to the re-establishment and maintenance of the diversity of carabid assemblages in the studied area (Magura et al., 2000).

It has been recently stressed that a forest patch needs to be of a minimum size to create conditions characteristic for forest interior species (Lövei et al., 2006). Critical values of forest size in boreal forests are species specific (Halme and Niemelä, 1993), different species responding to different habitat fragmentation (Davies and Margulles, 1998). Levenson (1981) estimated that in the deciduous forest zone of the eastern United States, habitat islands smaller than 2.3 ha may 


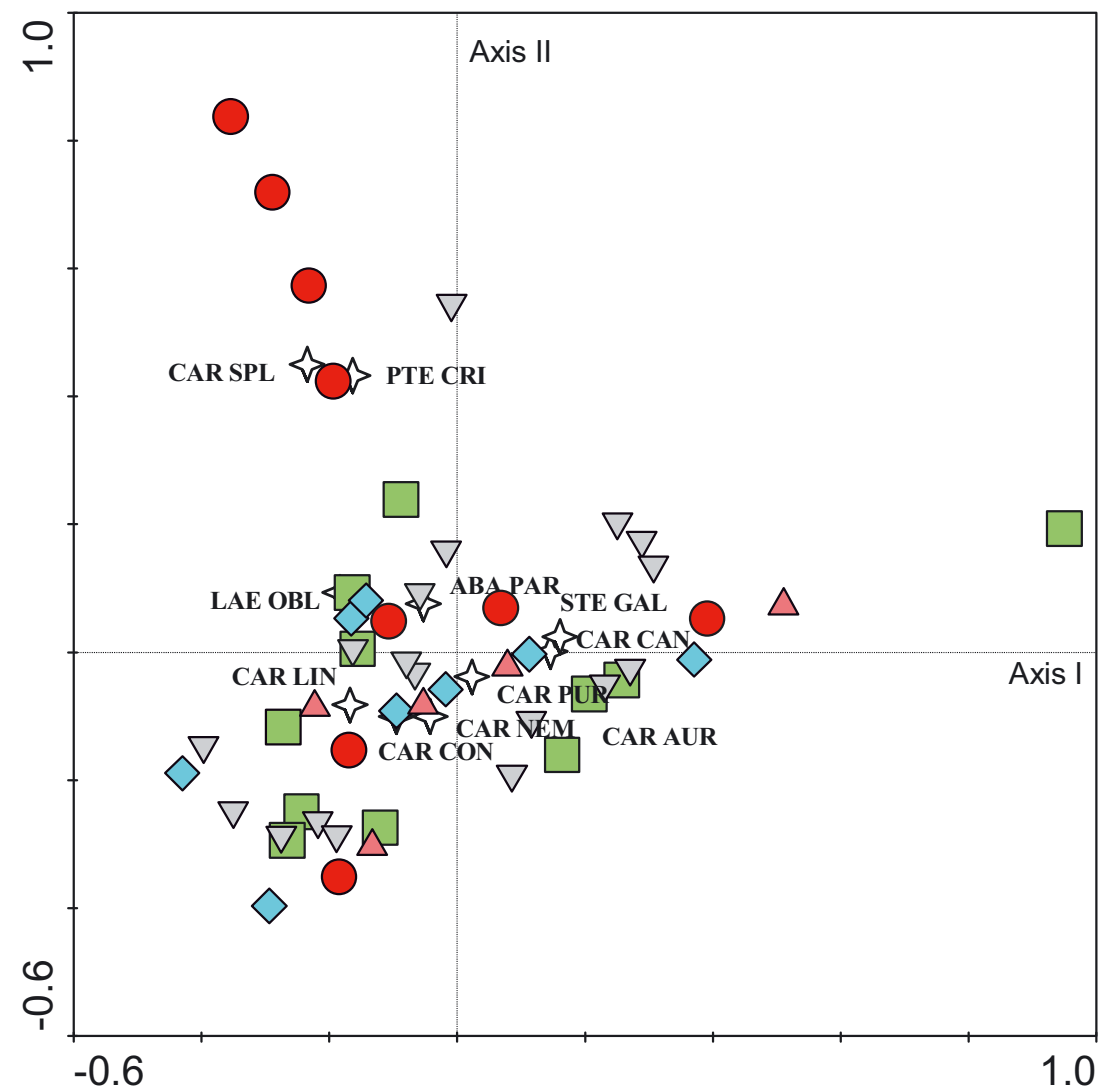

Figure 3. CA ordination diagram of carabid communities. Only species with a weight range higher than 1\% are represented. MF: squares, BE: circles, HO: diamonds, MP: up-triangles, PR: down-triangles. Species are named with the first three letters of their generic and the first three letters of their species names (e.g. ABA PAR: Abax parallelepipedus) and marked with stars. For species abbreviation see Table I.

Table III. Summary statistics of the CA ordination of carabid beetle communities.

\begin{tabular}{|c|c|c|c|c|c|}
\hline Axes & 1 & 2 & 3 & 4 & Total inertia \\
\hline Eigenvalues & 0.287 & 0.238 & 0.128 & 0.112 & 1.306 \\
\hline Cumulative $\%$ variance of species data & 22.0 & 40.2 & 49.9 & 58.5 & \\
\hline Sum of all eigenvalues & & & & & 1.306 \\
\hline
\end{tabular}

Table IV. Summary statistics of the CCA ordination of carabid beetle communities and ecological variables.

\begin{tabular}{|c|c|c|c|c|c|c|}
\hline Axes & & 1 & 2 & 3 & 4 & Total inertia \\
\hline Eigenvalues & & 0.180 & 0.092 & 0.051 & 0.042 & 1.599 \\
\hline Species-environment correlations & & 0.856 & 0.802 & 0.741 & 0.498 & \\
\hline \multicolumn{7}{|l|}{ Cumulative percentage variance of: } \\
\hline species data & & 11.3 & 17.0 & 20.2 & 22.9 & \\
\hline species-environment relation & & 41.7 & 63.0 & 74.9 & 84.7 & \\
\hline Sum of all eigenvalues & & & & & & 1.599 \\
\hline Sum of all canonical eigenvalues (explaine & ion) & & & & & $0.432(27 \%)$ \\
\hline \multicolumn{7}{|l|}{ Monte Carlo test } \\
\hline \multirow[t]{3}{*}{ Test of significance of first canonical axis } & eigenvalue & & 0.180 & & & \\
\hline & $F$-ratio & & 5.210 & & & \\
\hline & $P$-value & & 0.0540 & & & \\
\hline \multirow[t]{3}{*}{ Test of significance of all canonical axes } & Trace & & 0.432 & & & \\
\hline & $F$-ratio & & 1.518 & & & \\
\hline & $P$-value & & 0.0580 & & & \\
\hline
\end{tabular}




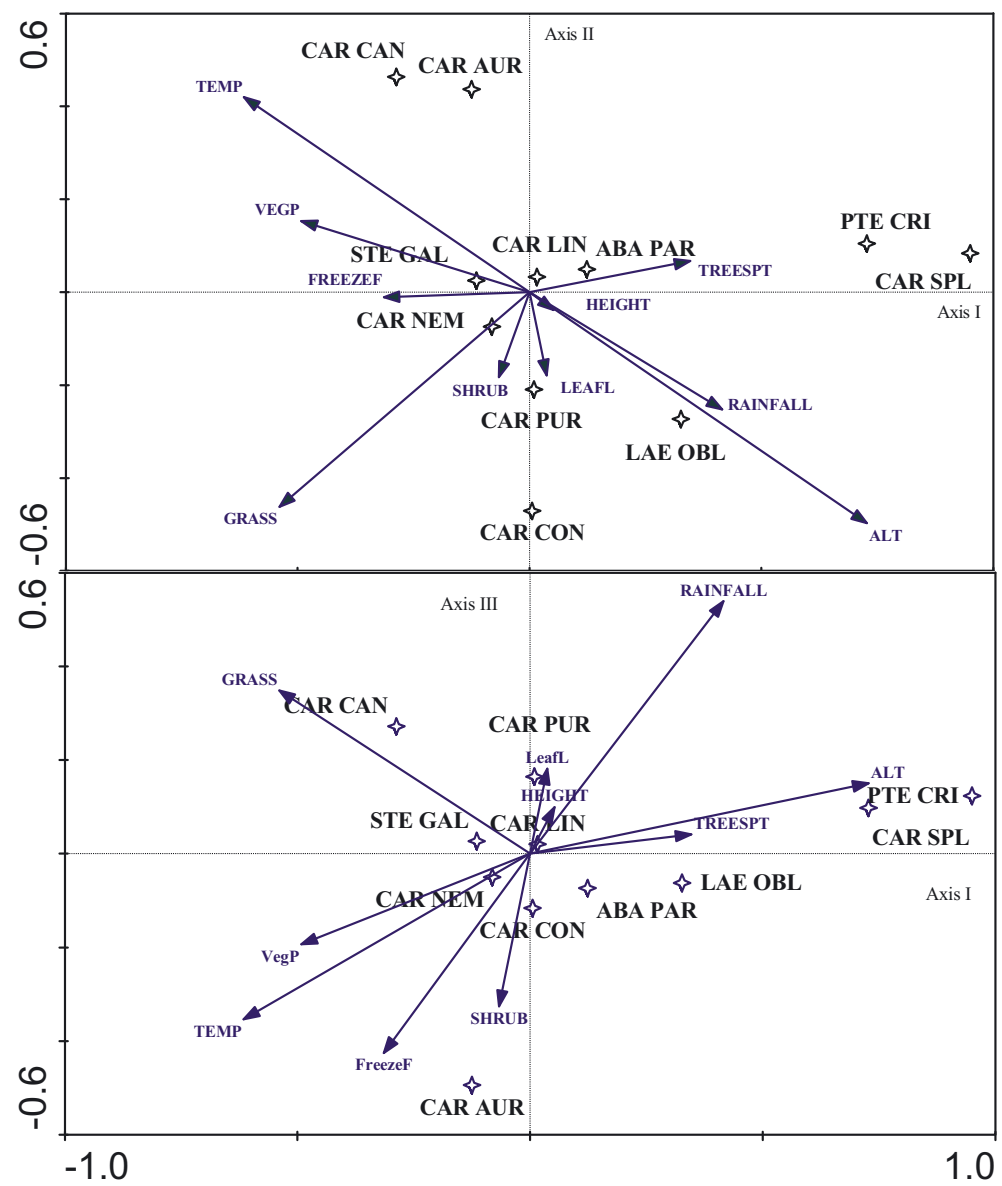

Figure 4. CCA ordination diagram of carabid communities and ecological variables (above axis I,II; below axis I,III). Only species with a weight range higher than $1 \%$ are represented. Species are named with the first three letters of their generic and the first three letters of their species names (e.g. ABA PAR: Abax parallelepipedus) and marked with stars. Ecological variables are represented by arrows. For species abbreviation see Table I. ALT: Altitude $(\mathrm{m})$, TEMP: Temperature $\left({ }^{\circ} \mathrm{C}\right)$, RAINFALL: rainfall $\left(\mathrm{mm}^{3}\right)$, FREEZEF: freeze free period (months), VEGP: vegetative period (months), HEIGHT: tree height (m), LEAFL: leaf litter layer cover (\%), SHRUB: shrub cover (\%), GRASS: grass cover (\%), TREESPT: total number of tree species present.

function essentially as edge communities. Very small islands $(<0.5$ ha) may be composed entirely of edges with no remaining core area where species characteristic of the continuous natural habitat would live (Mader, 1984). However, more recent studies estimated that the minimum size of a patch to maintain an intact assemblage of carabids is at least tens of hectares (Niemelä, 2001).

In the studied area it was not possible to find only forest patches of tens of hectares, moreover some of the sampled sites were located in patches smaller than 2.3 ha. Thus, applying Levenson's and Niemelä's estimates to our research, it might be taken into account that some of the forest patches were edge habitats (i.e. "deteriorated" forest habitat) and therefore they did not support pure forest carabid assemblages but had mixtures of forest and open habitat species (Halme and Niemelä, 1993).

The Ibaizabal basin is very industrialized and affected by humans (Orive and Rallo, 2002), with a limited degree of conservation characterized by small and fragmented patches of native forest surrounded by unmanaged plantations of $P$. $r a$ diata. According to this, lower carabid diversity in P. radiata plantations and differences among native and non native forest were expected. However our data are contradictory to this expectation. We suggest that similarity in carabid diversity in the analyzed habitats could be a consequence of the high habitat homogenization.

Forest management is uncommon in Basque plantations. From the eighth year until the site is clear-felled there is no cleaning of understorey vegetation (Martres and Tomé, 2002) allowing many pine plantations to support native communities of young trees, shrubs and herbs (Aseginolaza, 1996) that provide many microhabitats for the establishment of carabid assemblages coming from the surrounding habitats.

Several previous studies demonstrated that carabid species can be classified according to their spatial pattern into habitat generalists, forest generalists, forest specialists and species of open habitats (de Warnaffe and Lebrun, 2004; Niemelä and Halme, 1992; Magura et al., 2000). In this study species 
characterising a habitat type were found only in sites with native trees in the canopy: atlantic mixed forest, beech forest and mixed pine plantations (Fig. 1). Even many years after clear-cutting and plantation creation, there are no viable populations of typical native forest species, and there are no characteristic species of the non-native plantation (Magura et al., 2000). The clear-cutting and mechanical soil preparation before reforestation, as well as the establishment of even-aged conifer plantations without deciduous trees, contribute to the homogenisation of the previously heterogeneous habitats. All of these practices influence the forest specialist carabids directly (Magura et al., 2005). However, some deciduous forest species can survive in plantations (Spence et al., 1996), and can establish representative communities as happened with Laemostenus oblongus and Carabus macrocephalus in the mixed pine plantations. Although some forest specialists were found using the IndVal, their abundance represents less than a $10 \%$ of the captures per forest type (Fig. 2). A lack of forest specialist species might indicate some changes in the factors of the natural environment (Halme and Niemelä, 1993). These changes are caused by landscape fragmentation (Niemelä et al., 1994), the creation of small natural forest patches and above all, the transformation of original native forest into non-native homogeneous even aged plantations.

Other studies showed that carabid species composition presented differentiated distributions across the habitat types (Butterfield et al., 1995; Halme and Niemelä, 1993; Magura et al., 1997; 2000; 2003; Migliorini et al., 2002). Moreover distribution patterns and composition seem to be related to habitat heterogeneity at various spatial scales (Niemelä and Halme, 1992; Penev, 1996). Our study however presents very different results. The species composition of the assemblages was quite similar (Fig. 3). Different forest types were represented by the same species assemblages, sharing most carabid communities. Only specific populations of Carabus splendens and Pterostichus cristatus have been detected in some beech forests. The overlapped distribution of the remaining communities shows clear habitat related homogeneity that leads to a poor differentiation in the distribution pattern of the studied species.

Carabids are mostly polyphagous feeders that consume animal (live prey and carrion) and plant material (Lövei and Sunderland, 1996), their distributions depend to a considerable extent on environmental variables such as moisture, soil density and altitude (Luff et al., 1992), as well as prey abundance (Halme and Niemelä, 1993; Niemelä and Spence, 1994). Another important factor affecting carabid distribution by maintaining habitat heterogeneity (Magura et al., 2003; 2005) is the amount of deciduous leaf litter (Magura et al., 2000; 2005; Poole et al., 2003). Leaf-litter addition could alter the microclimatic conditions influencing the spatial pattern and the composition of carabid abundance, species richness and diversity (Magura et al., 2000; 2005). Other authors found important relationships between carabid composition and ecological variables, including old deciduous woodland patches, vertical stand structure (Barbaro et al., 2005; Humphrey et al., 1999), shrub cover (Barbaro et al., 2005), cover of herbs (Magura et al., 2005), latitude, canopy structure, soil organic matter and vegetation diversity (Jukes et al., 2001).

Stand age is also considered likely to influence carabid communities. Previous studies showed that stands of various ages covered with the same forest habitat type had different carabid assemblages (Niemelä et al., 1993). Baguette and Gérard (1993) found that the species composition and richness of carabid communities in spruce plantations differed significantly among the studied age classes. On the contrary for Elek et al. (2001), abundance and species richness did not present significative differences among spruce plantations of different ages.

Among the ecological variables analysed in our study, one set was significantly related to the carabid species community (Fig. 4). The most influential variables for the community were altitude, percentage of grass layer and temperature. However important variables for other authors, including leaf litter layer, shrub layer, tree height and tree species composition, did not seem to play an important role in the carabid assemblages in the Ibaizabal basin. Dominant species (Steropus gallega, Carabus nemoralis, Abax parallelepipedus, Carabus lineatus and Carabus purpurascens) did not show habitat preferences based on the analyzed ecological variables. In regard to our results less abundant species were more sensitive and showed more specific habitat requirements. Carabus splendens and Pterostichus cristatus presented a distribution linked to beech forest (Figs. 1 and 3). As in the basin, beech forest growth at higher elevations, it could be expected that both species were influenced by altitude. Laemostenus oblongus was a characteristic species of mixed pine plantations and was also influenced by altitude, and this could affect its occasional presence in some beech forest stands. Carabus convexus and C. cancellatus were defined by the IndVal as forest generalists with lower index value. Carabus convexus showed a response to the percentage of grass coverage and altitude, whereas $C$. cancellatus was influenced by the percentage of grass coverage and temperature. This might indicate that although both species were present in each of the studied forest types, they exhibit some kind of habitat preferences. Carabus auratus seems to be clearly linked to warm areas, as the main variables influencing this species distribution are temperature and freeze free months. The species shows more affinity to the regularly mild climatic conditions typical of the atlantic mixed forest from the Ibaizabal basin, and therefore it was defined as a characteristic species for atlantic mixed forest.

In the Ibaizabal basin, native forest and non-native pine plantations show very similar carabid communities composed mostly of forest generalist species, indicating a lack of suitable habitats for specialist species. High habitat homogenization caused, on one side by the regeneration of the indigenous understorey in pine plantations, and on the other side by the poor habitat quality of native forest (antropized patchy remnants enclosed in conifer plantations), could be the reason to explain the similar carabid diversity.

In order to confirm these results, studies on target forest on high habitat quality in the region should be carried out. 
Acknowledgements: We thank Mr. Alejandro Cantero (IKT) and his team for field work and Mr. Carlos Herrán for his laboratory helps. To Dr. Hervé Jactel (Pierroton, INRA) for inviting us to participate in the FORSEE project and Mrs. Inge van Halder (Pierroton) and Dr. Marc Dufrêne (Centre de Recherche de la Nature des Forêts et $\mathrm{du}$ Bois) for their help with the IndVal. To Dr. Niemelä (University of Helsinki), Dr. Magura (Debrecen University) and two anonymous referees for their critical comments. We are also grateful to Prof. Dr. Farrel (University College, Dublin) and Dr. Laurence Mound (CSIRO Entomology, Australia) for their English revision. This work was funded by European Union (FEDER), INTERREGIIIb and the Department of Agriculture, Fisheries and Food of the Basque Government who granted Mrs. Martinez with a Ph. D. scholarship.

\section{REFERENCES}

Aseginolaza Iparragirre C., 1996. Vegetación de la Comunidad Autónoma del País Vasco, Dpto. de Ordenación del Territorio, Vivienda y Medio Ambiente, Gobierno Vasco, Vitoria-Gasteiz, $361 \mathrm{p}$.

Baguette M. and Gérard S., 1993. Effects of spruce plantations on carabid beetles in southern Belgium. Pedobiologia 37: 129-140.

Barbaro L., Pontcharraud L., Vetillard F., Guyon D., and Jactel H., 2005. Comparative responses of bird, carabid, and spider assemblages to stand and landscape diversity in maritime pine plantation forests. Écoscience 12: 110-121.

Brandmayr P., Colombetta G., and Polli S., 1983. Waldcarabides des Triester Karstes als Indikatoren des makroklimatischen Überganges vom kontinentalen Europa zur Mediterraneis (Coleoptera, Carabidae). Zool. Jb. Syst. 110: 201-220.

Butterfield J., 1992. The effect of conifer plantations on the invertebrate communities of peat moorland. In: Bragg O.M., Robertson P.D. and Ingram H.A.P. (Eds.), Peatland ecosystems and man: an impact assessment. International Peat Society, Cambridge University Press, Cambridge, pp. 309-315.

Butterfield J., Luff M.L., Baines M., and Eyre M.D., 1995. Carabid beetle communities as indicators of conservation potential in upland forests. For. Ecol. Manage. 79: 63-77.

Davies K.F. and Margules C.R., 1998. Effects of habitat fragmentation on carabid beetles: experimental evidence. J. Anim. Ecol. 67: 460-471.

De Groot R., 2006. The concept of ecosystem goods and services, Abstracts of the scientific forum of the International Congress on Cultivated Forests, 3-7 October, Bilbao, Spain.

De Warnaffe G. and Lebrun P., 2004. Effects of forest management on carabid beetles in Belgium: implications for biodiversity conservation. Biol. Conserv. 118: 219-234.

Dufrêne M. and Legendre P., 1997. Species assemblages and indicator species: the need for a flexible asymmetrical approach. Ecol. Monogr. 67: 345-366.

Elek Z., Magura T., and Tóthmérész B., 2001. Impacts of non-native Norway spruce plantation on abundance and species richness of ground beetles (Coleoptera: Carabidae). Web Ecol. 2: 32-37.

Fahy O. and Gormally M., 1998. A comparison of plants and carabid beetle communities in an Irish oak woodland with a nearby conifer plantation and clearfelled site. For. Ecol. Manage. 110: 263-273.

GESPLAN, 2002. Sistema de cartografía ambiental de la C.A.P.V., Departamento de Ordenación del Territorio, Vivienda y Medio ambiente del Gobierno Vasco, Vitoria-Gasteiz.

Gutiérrez D., Menéndez R., and Méndez, M., 2004. Habitat-based conservation priorities for carabid beetles within the Picos de Europa National Park, northern Spain. Biol. Conserv. 115: 379-393.

Halme E. and Niemelä J., 1993. Carabid beetles in fragments of coniferous forest. Ann. Zool. Fenn. 30: 17-30.
Humphrey J.W., Hawes C., Peace A.J., Ferris-Kaan R., and Jukes M.R., 1999. Relationships between insect diversity and habitat characteristics in plantation forests. For. Ecol. Manage. 3: 11-21.

Hùrka K., 1996. Carabidae of the Czech and Slovak Republics. Kabourek, Zlín, 565 p.

Ings T.C. and Hartley S.E., 1999. The effect of habitat structure on carabid communities during the regeneration of a native Scottish forest. For. Ecol. Manage. 119: 123-136.

Inventario Forestal de la Comunidad Autónoma Vasca, 2005. Departamento de Agricultura, Pesca y Alimentación del Gobierno Vasco, [on line] avalaible at: http://www.nasdap.ejgv.euskadi.net/ r50-15135/es/contenidos/estadistica/inven_fores_tabla3/es_dapa/ inven_fores_tabla3.html, Accessed: junio 2007.

IFN2, 1998. Villaescusa R. and Díaz R., 1998. Segundo Inventario Forestal Nacional (1986-1996), Ministerio de Medio Ambiente, ICONA, Madrid.

Jactel H., Brockerhoff E., and Duelli P., 2004. A test of the biodiversitystability theory: Meta-analysis of tree species diversity effects on insect pest infestations, and re-examination of responsible factors. In: Scherer-Lorenzen M., Körner C., and Schulze E. D. (Eds.), Forest Diversity and Function, Ecological Studies 176, Springer Verlag, Berlin, pp. 235-262.

Jeannel R., 1941. Coléoptères Carabiques, première partie. Faune de France 39, Lechevalier, Paris, 571 p.

Jeannel R., 1942. Coléoptères Carabiques, seconde partie. Faune de France 40, Lechevalier, Paris, 600 p.

Jiménez-Valverde A. and Ortuño V.M., 2007. The history of endemic Iberian ground beetle description (Insecta, Coleoptera, Carabidae): which species were described first? Acta Oecol. 31: 13-31.

Jukes M.R., Peace A.J., and Ferris R., 2001. Carabid beetle communities associated with coniferous plantations in Britain: the influence of site, ground vegetation and stand structure. For. Ecol. Manage., 148: 271-286.

Landres P.B., Verner J., and Thomas J.W., 1988. Ecological uses of vertebrate indicator species: a critique, Conserv. Biol. 2: 316-328.

Lenski R.E., 1982. Effects of forest cutting on two Carabus species: evidence for competition for food. Ecology 63: 1211-1217.

Levenson J.B., 1981. Woodlots as biogeographic islands in south-eastern Wisconsin. In: Burgess R.L. and Sharpe D.M. (Eds.), Forest island dynamics in man-dominated landscapes, Springer Verlag, New York, pp. 13-39.

Loidi J., Herrera M., Salcedo I., Galarza A., and Iturrondobeitia J.C., 2005. Bizkaiko basoak, Los bosques de Bizkaia, Instituto de Estudios Territoriales de Bizkaia, Bilbao, 383 p.

Lövei G. and Sunderland K.D., 1996. Ecology and behavior of ground beetles (Coleoptera: Carabidae). Annu. Rev. Entomol. 41: 231-256.

Lövei G.L., Magura T., Tóthmérész B., and Ködöböcz V., 2006. The influence of matrix and edges on species richness patterns of ground beetles (Coleoptera: Carabidae) in habitat islands. Global Ecol. Biogeogr. 15: 283-289.

Luff M.L., Eyre M.D., and Rushton S.P., 1992. Classification and prediction of grassland habitats using ground beetles (Coleoptera: Carabidae), J. Environ. Manage. 35: 301-315.

Mader H.J., 1984. Animal habitat isolation by roads and agricultural fields. Biol. Conserv. 29: 81-96.

Magura T., 2002. Carabids and forest edge: spatial pattern and edge effect. For. Ecol. Manage. 157: 23-37.

Magura T., Tóthmérész B., and Bordan Z., 1997. Comparison of the carabid communities of a zonal oak-hornbeam forest and pine plantations. Acta Zool. Hung. 43: 173-182. 
Magura T., Tothmérész, B., and Bordán Z., 2000. Effects of nature management practice on carabid assemblages (Coleoptera: Carabidae) in a non-native plantation. Biol. Conserv. 93: 95-102.

Magura T., Tóthmérész B., and Elek Z., 2003. Diversity and composition of carabids during a forestry cycle. Biodivers. Conserv. 12: 73-85.

Magura T., Tóthmérész B., and Elek Z., 2005. Impacts of leaf-litter addition on carabids in a conifer plantation. Biodivers. Conserv. 14: $475-491$.

Martres J.L. and Tomé M., 2002. Forest Atlas of the South Atlantic Arc. IEFC, USSE and Eurosilva Sur, Vitoria-Gasteiz, 78 p.

Migliorini M., Petrioli A., and Bernini F., 2002. Comparative anlysis of two edaphic zoocoenoses (Oribatid mites and Carabid beetles) in five habitats of the "Pietraporciana" and "Lucciolabella" Nature Reserves (Orcia Valley, central Italy). Acta Oecol. 23: 361-374.

Montreal Process, 2000. Montreal Process Year 2000 Progress ReportProgress and innovation in implementing criteria and indicators for the conservation of sustainable management of temperate and boreal forests. The Montreal Process Liaison Office. Canadian Forest Service, Otawa, Canada.

Niemelä J., 2001. Carabid beetles (Coleoptera: Carabidae) and habitat fragmentation: a review. Eur. J. Entomol. 98: 127-132.

Niemelä J. and Halme H., 1992. Habitat associations of carabid beetles in fields and forests on the Åland Islands, SW Finland. Ecography 15: $3-11$.

Niemelä J. and Spence J.R., 1994. Distribution of forest dwelling carabids (Coleoptera): spatial scale and the concept of communities. Ecography 17: 166-175.

Niemelä J., Langor D., and Spence J.R., 1993. Effects of clear-cut harvesting on boreal gorund beetle assemblages (Coleoptera: Carabidae) in western Canada. Conserv. Biol. 7: 551-561.

Niemelä J., Spence J.R., Langor D., Haila Y., and Tukia H., 1994. Logging and boreal gorund beetle assemblages on two continents: implications for conservation. In: Gaston K., Samways M. and New T. (Eds.), Perspectives in insect conservation, Intercept Publications, Andover, pp. 29-50.

Niemelä J., Kotze J., Ashworth A., Brandmayr P., and Desender, K., 2000. The search of common anthropogenic impacts on biodiversity: a global network. J. Insect Conserv. 4: 3-9.

Niemelä J., Koivula M., and Kotze D.J., 2007. The effects of forestry on carabid beetles (Coleoptera: Carabidae) in boreal forests. J. Insect Conserv. 11: 5-18.

Orive E. and Rallo A., 2002. Ríos de Bizkaia /Bizkaiko Ibaiak. Instituto de Estudios Territoriales de Bizkaia, ZURE, Bizkaia, 258 p.
Ortubay A., 1995. Relación clima-vegetación en la Comunidad Autónoma del País Vasco. Dpto. de Industria, Agricultura y Pesca, Tésis doctorales $\mathrm{n}^{\circ}$ 27, Servicio Central de Publicaciones del Gobierno Vasco, Vitoria-Gasteiz, 506 p.

Ortuño V.M. and Marcos J.M., 2003. Los Caraboidea (Insecta: Coleoptera) de la Comunidad Autónoma del País Vasco (Tomo 1). Dpto. de Medio Ambiente y Ordenación del Territorio. Servicio Central de Publicaciones del Gobierno Vasco, Vitoria-Gasteiz, 573 p.

Pearce L.P. and Venier L.A., 2006. The use of ground beetles (Coleoptera: Carabidae) and spiders (Araneae) as bioindicators of sustainable forest management: A review. Ecol. Indic. 6: 780-793.

Penev L., 1996. Large-scale variation in carabid assemblages, with special reference to the local fauna concept, Ann. Zool. Fenn. 33: 49-63.

Pimm S.L. and Gilpin M.E., 1989. Theoretical issues in conservation biology. In: Roughgarden J., May R.M., and Lewin S.A. (Eds.), Perspectives in Ecological Theory, Princeton University Press, Princeton, New Jersey, pp. 287-305 .

Poole A., Gormally M., and Skeffington M.S., 2003. The flora and carabid beetle fauna of a nature and regenerating semi-natural oak woodland in south-east Ireland. For. Ecol. Manage. 177: 207-220.

Rainio J. and Niemelä J., 2003. Ground Beetles (Coleoptera: Carabidae) as bioindicators. Biodivers. Conserv. 12: 487-506.

Serrano J., 2003. Catálogo de los Carabidae: Coleoptera de la Península Ibérica. Monografías de la Sociedad Entomólogica Aragonesa, Vol. 9, Zaragoza, $130 \mathrm{p}$.

Sokal R.R. and Rohlf F.J., 1981. Biometry, Freeman, New York.

Spence J.R., Langor D.W., Niemelä J., Cárcamo H.A., and Currie C.R., 1996. Northern forestry and carabids: the case for concern about oldgrowth species. Ann. Zool. Fenn. 33: 173-184.

Taboada A., Kotze J., Tárrega R., and Salgado J., 2006. Traditional forest management: do carabid beetles respond to human-created vegetation structures in an oak mosaic landscape? For. Ecol. Manage. 237: 436-449.

Ter Braak C.J.K. and Šmilauer P., 1998. CANOCO Reference Manual and User's Guide to CANOCO for Windows: Software for Canonical Ordination (version 4), Microcomputer Power, Ithaca, New York, $352 \mathrm{p}$.

Thiele H.-U., 1977. Carabid Beetles in their Environments, A study on Habitat Selection by Adaptations in Physiology and Behaviour, Springer, Berlin, $369 \mathrm{p}$.

UNCSD, 2007. Indicators of sustainable development: guidelines and methodologies 2001, [online] available at: http://www.un.org/ esa/sustdev/natlinfo/indicators/isd_guidelines_note.htm, Accessed: February 2007. 